\title{
甲状腺混合髄様濾胞癌と乳頭癌合併例
}

\author{
岩城 詠子・山本 健人・齋藤等・今村 好章*
}

\section{A Case of Mixed Medullary and Follicular Carcinoma of the Thyroid Accompanied by Papillary Carcinoma}

\author{
Eiko Iwaki, Takehito Yamamoto, Hitoshi Saito and Yoshiaki Imamura \\ (Fukui Medical School)
}

\begin{abstract}
We report here a case of an unusual thyroid carcinoma. A 72-year-cld woman was admitted for a thyroid tumor resection. The serum calcitonin level was elevated markedly at $967 \mathrm{pg} / \mathrm{ml}$ (normal range : $<40 \mathrm{pg} / \mathrm{ml}$ ), and the serum thyroglobulin and CEA levels were also elevated. A total thyroidectomy with left neck dissection was then performed. Two tumors were removed : a $10 \times 20 \mathrm{~mm}$ tumor from the right lobe and a $30 \times 40 \mathrm{~mm}$ tumor from the left lobe, and some lymph nodes were also resected from the left neck. The pathological examination revealed that the right sided tumor was a papillary carcinoma, and that the left sided tumor was composed of medullary carcinoma cells interspersed with follicles containing colloid. The resected lymph nodes included some of the same cells that were present in the left sided tumor. Further examination using immunoperoxidase staining demonstrated that the cells were immunopositive for both calcitonin and thyroglobulin. Therefore, we diagnosed the left sided tumor as a mixed medullary and follicular carcinoma. Three years have passed since the operation, but no recurrence has been recognized.
\end{abstract}

Key words : mixed medullary and follicular carcinoma, papillary carcinoma, calcitonin, thyroglobulin, immunoperoxidase staining

\section{はじめに}

\section{甲状腺䯣様癌は甲状腺癌の中では比較的稀な腫瘍であ} るが，近年䯣様癌に濾胞癌の混在した, mixed medullary and follicular carcinoma (MFC) が少数ながら報告され るよらになった．MFCは䯣様癌の一亜型として位置づ けられており, 䯣様癌の形態と, 濾胞癌の形態を合わせ 持つ腫瘍で, その両者がそれぞれカルシトニン, サイロ グロブリンの免度活性を持つものとされているが，その 組織発生, 生物学的特性については不明な点が多い.

今回我々は MFC に，乳頭癌を合併した症例を経験し たので報告する.

\section{症例}

症例 : 72歳, 女性.

主訴: 前頸部腫瘤.

既往歴, 家族歴 : 特記すべきことなし.

現病歷：1992年10月頃より呼吸困難感が生じ, 近医受 診した際, 前頸部腫瘤を指摘され, 精查目的に当科紹介 受診した. 外来にて行った諸検査の結果, 甲状腺腫瘍の 診断にて，同年11月30日手術目的に当科入院となった.

入院時現症 : 耳鼻咽喉には特記所見はなかった。頸部 は甲状腺右葉に当たる部位に径約 $1 \mathrm{~cm}$, 左葉に当たる 部位に径約 $2 \mathrm{~cm}$ の弾性硬の腫瘤を触知した。頸部リン 八節は触知しなかった。全身状態は良好で, 発熱, 下痢, 
動悸など髄様癌にしばしば見られる特徵的な症状は認め なかった。

血液学的検査：血清 Ca 值を含めた一般血液検查和上 び，TSH，Free $\mathrm{T}_{4}$, Free $\mathrm{T}_{3}$ は正常範围であった。サイ ログロブリンは $81.1 \mathrm{ng} / \mathrm{ml}$ (正常值 $<40 \mathrm{ng} / \mathrm{ml}$ )，カル シトニンは $967 \mathrm{pg} / \mathrm{ml}$ (同 $<100 \mathrm{pg} / \mathrm{ml}), C E A$ は 121 $\mathrm{ng} / \mathrm{ml}$ (同 $<2.5 \mathrm{ng} / \mathrm{ml})$ と矢れぞれ上昇認めた。

画像検査: CT (図 1 ) 上, 甲状腺右葉に径 $1 \mathrm{~cm}$ の低 吸収の腫瘍像を，また左葉には径 $2.5 \mathrm{~cm}$ で石灰化を伴 った内部の不均一な腫瘍を認めた。頸部ェコー上，右葉 には境界不明膫な充害性の腫瘤を, 左葉には境界不明膫 で内部ェコー不均一な腫瘤を認めた。タリウムシンチグ ラフィーでは両葉とも集積を見たが， delayed scan では 陰性であった。

以上の検査結果より甲状腺髄様癌が強く疑われたため, 上皮小体，副腎の検索も行ったが腫瘍や，機能障害は認 められなかった，尿中カテュラミン值も正常範囲であっ た。散発性䯣様癌の診断にて1992年12月 3 日手術を行っ た。

手術所見：全身麻酔下，前頸部切開にて甲状腺を露出 したところ両葉に腫瘍が存在し，甲状腺全摘を行った。 右頸部にはリンパ節は存在しなかったが，左頸部には大 小のリンパ節が存在したため, 左頸部郭清術も行い, 13 個のリンパ節を摘出した。両側反回神経は温存したが， 上皮小体は確認できなかった。

摘出標本：甲状腺右葉に $10 \times 20 \mathrm{~mm}$ の充実性腫瘍が,

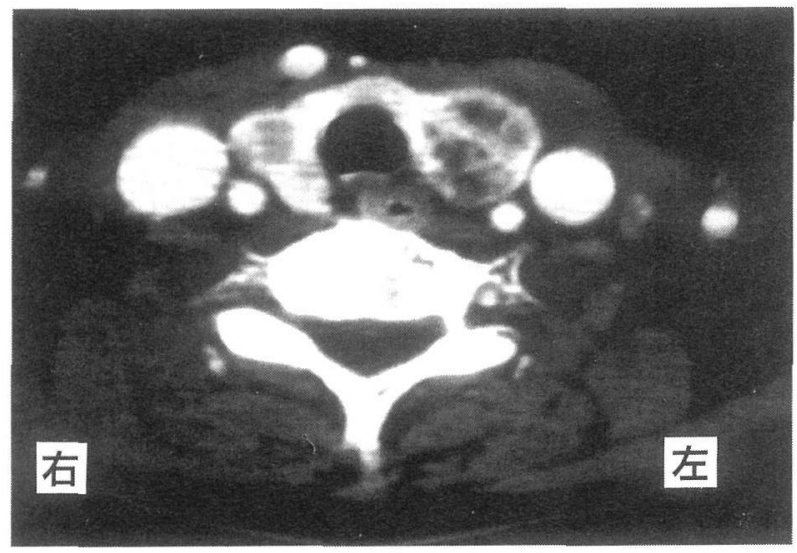

図 1 術前の CT 像

右葉に径 $1 \mathrm{~cm}$, 左葉に径 $2.5 \mathrm{~cm}$ の腫瘍像を認內る.
左葉には被膜を持たない $30 \times 40 \mathrm{~mm}$ の，石灰化を伴っ た多房性の腫瘍が存在した。

病理組織所見: H-E 染色では右葉の腫瘍(図 2 ) は特 徵的な乳頭状構造を持ち, 核はすりガラス状で, 所々に 核溝も見られ典型的な乳頭癌の像を示していた。左葉の 腫瘍(図 3 ) は大小不同の核之広く顆粒状の細胞質を持っ た腫瘍細胞が充実性に增殖し，髄様癌を思わせるが一部 にはコロイドを含んだ滤胞を形成していた．左頸部より 摘出した転移リンパ節も, 左葉摘出標本と同様の細胞か らなり、ところどころ濾胞構造を示していた(図4)、コ ンゴーレッド染色では間質にアミロイドの沈着が見られ

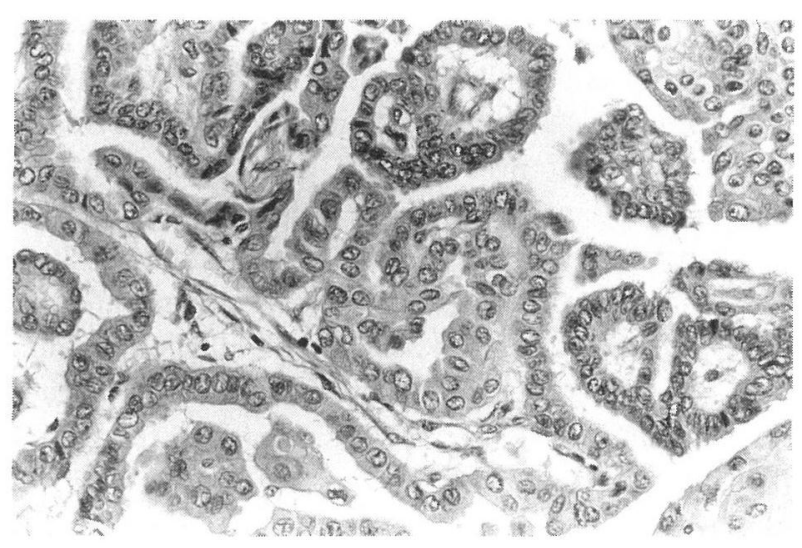

図 2 H-E 染色標本 (右葉の腫瘍) $(\times 400)$

乳頭状構造を示す細胞の核はすりガラス状で, 所々に核 溝も見られ，典型的な乳頭癌の像を示している。

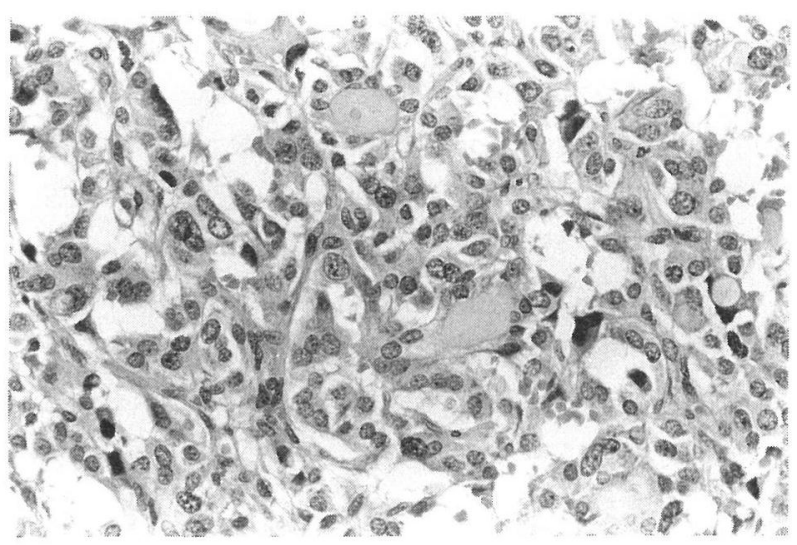

図 3 H-E 染色標本 (左葉の腫瘍) ( $\times 400)$

大小不同の核と広く顆粒状の細胞質を持った腫瘍細胞が 充実性に増殖し，一部にはコロイドを含えだ濾胞を形成 している. 
た，左葉および転移リン八゚節は䯣様癌と濾胞癌が混在し いわゆる混合癌と考光られた。このことを確認するため さらに特殊染色を行った，左葉の標本に酵素抗体法にて カルシトニン染色を行らと、汪とんどすべての細胞質が 褐色に染まりカルシトニン分泌が盛んなことが示唆され た(図 5 )。ささらに滤胞上皮マーカー物質であるサイログ ロブリンに上る染色を行っても褐色に染まる部分がみら れ，サイログロブリンを産生している腫瘍細胞もあるこ とがわからた(図6)，CEA 染色でも強陽性であった。

電顕(困 7 ) 像では, 左葉の腫瘍細胞は細胞質によく発 達した細胞内小器管と, 多数の神経内分泌顆粒が認めら れた。

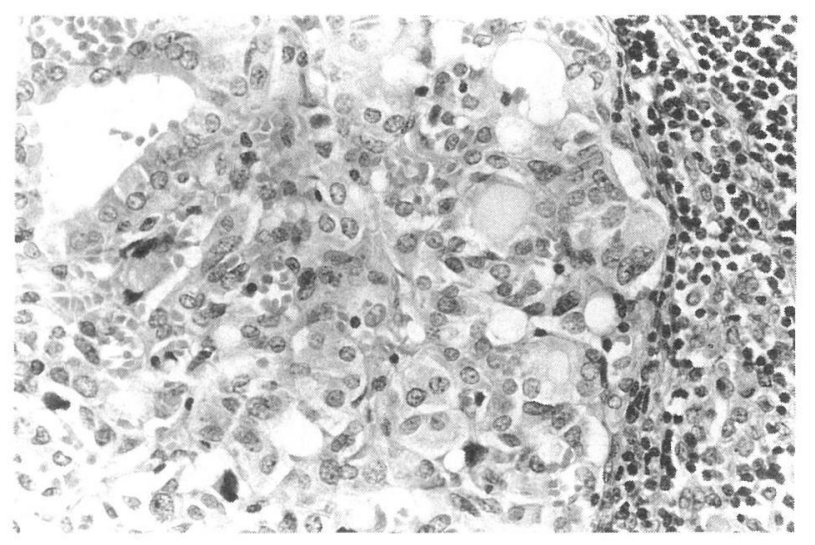

図 4 H-E 染色標本 (左頸部転移リンパ節) $(\times 400)$ 左葉摘出標本と同様の組織像を示す. 右方に一部正常り ンパ節組織が見られる.

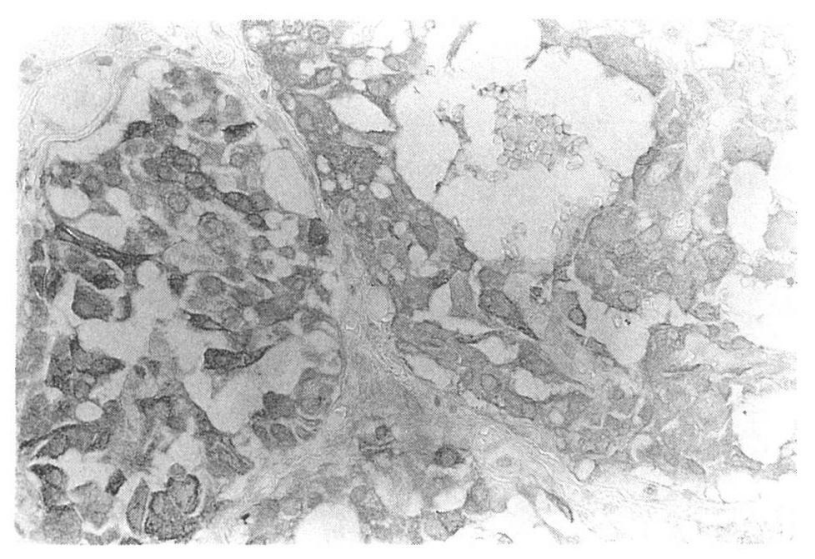

図 5 カルシトニン染色標本 (左葉の腫瘍) $(\times 400)$ 汪とんどすべての細胞の細胞質が褐色に染まっている，
これらの結果から, 左葉の腫瘍は䯣椂癌の形態と, 濾 胞癌の形態が混在した, mixed medullary and follicular carcinomaであり，こ扎に右葉の乳頭癌を合併したもの と診断された。

術後経過: 手術後, カルシトニン值は $96 \mathrm{pg} / \mathrm{ml}$, サイ ログロブリン值は $13.5 \mathrm{ng} / \mathrm{ml}, \mathrm{CEA}$ 值は $2.3 \mathrm{ng} / \mathrm{ml}$ と いずれも正常範囲まで下降した。これらの值の測定と,

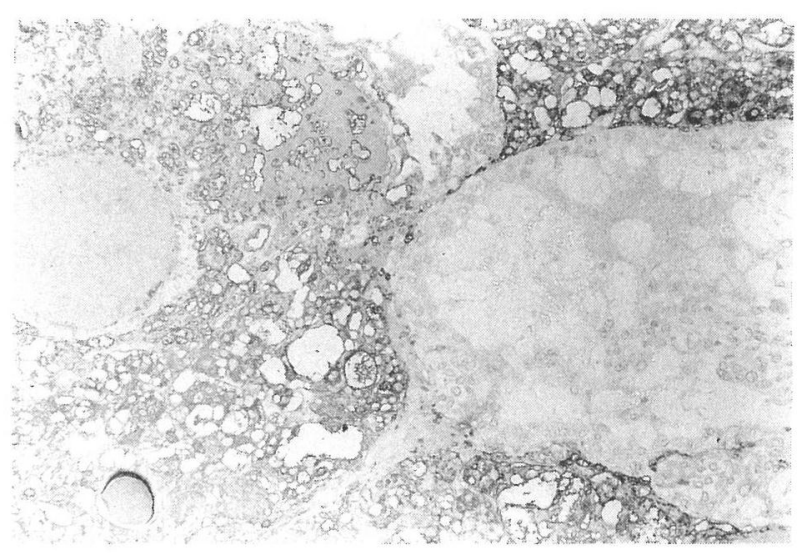

図 6 サイログロブリン染色標本 (左葉の腫瘍)（×100）

褐色に染まる部分が見られ, サイログロブリンを産生し ている腫瘍細胞も存在することがわかる.

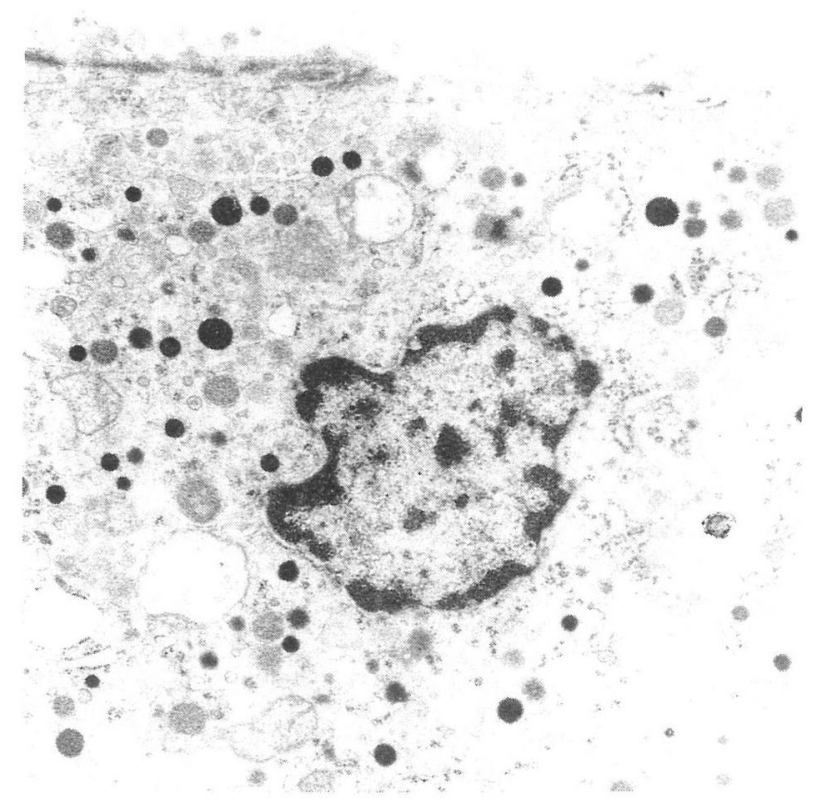

図 7 電顕所見 $($ 左葉の腫瘍細胞 $)(\times 7000)$ 細胞質に多数の神経内分泌顆粒が認められる. 
CT 検査を定期的に行い外来にて経過観察中であるが, 術後 3 年 1 カ月経過した現在再発は認めていない.

\section{考察}

以前より, 甲状腺髄様癌にコロイドを含んだ滤胞構造 を示す亜型が存在することが報告されてきた1) 3)が， 1982年に Hales ら ${ }^{4)}$ が甲状腺癌で mixed medullary and follicular pattern を示す腫瘍を報告して以来，同様の報

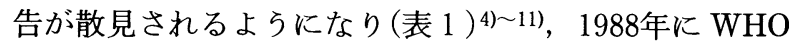
の甲状腺組織分類が改訂された際には，MFC も取り上 げられている12)

この中で，MFC は甲状腺䯣様癌の一亜型として位置 つけられており, 䯣様癌の形態と, 滤胞癌の形態を合わ せ持つ腫瘍で，両者がそれぞれカルシトニン，サイログ ロブリンの免度活性を示すものとして定義されている. そのため MFC の診断のためには, 抗カルシトニン抗体
抢よび抗サイログロブリン抗体を用いた免疫組織染色を 行い, 腫瘍細胞からのカルシトニンおよびサイログロブ リンの産生を証明することが必須であるが，標本作製の 際に正常濾胞が取り込まれてしまう場合や䯣様癌で濾胞 状構造をとるものと厳密に区別できないことから，その 転移巣にて両成分の発現を確認するなど慎重な検索が必 要であるとされている．また MFC 細胞がサイログロブ リンの免疫活性を示しても濾胞構造を示さなければ, MFC としての診断には不十分であると考えられている.

本症例では MFC の部分は䯣様癌に特徽的な腫瘍細胞 より構成され，酵素抗体法によるカルシトニン染色でも 陽性であったが，コロイドを含んだ滤胞を形成している 部分が観察され，しかもそれは標本の端などに偶然取り 込まれた正常濾胞とは異なり明らかに腫瘍内部に混在し ていた。 また濾胞形成部分の腫瘍細胞は酵素抗体法によ るサイログロブリン染色陽性であった。また転移巣を検

表 1 MFC 報告例

\begin{tabular}{|c|c|c|c|c|c|c|c|c|c|c|}
\hline & 報告者・年 & \begin{tabular}{|l|} 
年龄 \\
性別 \\
\end{tabular} & $\begin{array}{c}\mathrm{CT} \\
(\mathrm{pg} / \mathrm{ml}) \\
\end{array}$ & $\begin{array}{c}\text { TG } \\
\text { (ng/ml) }\end{array}$ & $\begin{array}{c}\text { CEA } \\
\text { (ng/ml) }\end{array}$ & $\begin{array}{l}\text { 頸部 } \\
\text { 転移 }\end{array}$ & 療 & 家族歴 & 腫瘍サイズ (mm) & 備 \\
\hline 1 & $\begin{array}{c}\text { Hales 54) } \\
1982 \\
\end{array}$ & 44, 男 & $\begin{array}{c}7800 \\
(0 \sim 90)\end{array}$ & $\begin{array}{c}145 \\
(10 \sim 50)\end{array}$ & $*$ & 有り & $\begin{array}{l}\text { 甲状腺全摘＋b-ND } \\
\text { 甲状腺ホルモン療法 }\end{array}$ & なし & $40 \times 35 \times 30$ & \\
\hline 2 & $\begin{array}{c}\text { Pfaltz } 5^{5)} \\
1983 \\
\end{array}$ & 35 , 男 & $*$ & $*$ & $*$ & 有り & 甲状腺全摘 + b-ND & * & $\begin{array}{c}50 \times 30 \times 30 \text { (右葉) } \\
20 \times 20 \times 10 \text { (錐体葉) }\end{array}$ & \\
\hline 3 & $\begin{array}{c}\text { Ljungberg } 5^{6)} \\
1983\end{array}$ & 45 , 女 & $*$ & $\begin{array}{l}>4000 \\
(<40)\end{array}$ & $*$ & 有り & $\begin{array}{c}\text { 甲状腺全摘 +r-ND } \\
\text { 甲状腺ホルモン療法 }\end{array}$ & なし & $40 \times 45 \times 60$ & $\begin{array}{l}4 \text { 年後, 肺, 脳転移 } \\
\text { にて死亡 }\end{array}$ \\
\hline 4 & $\begin{array}{c}\text { Parker } 5^{7)} \\
1985 \\
\end{array}$ & 51 , 男 & $\begin{array}{c}35000 \\
(<425)\end{array}$ & $*$ & $\begin{array}{c}188 \\
(<2.5)\end{array}$ & 有り & 甲状腺全摘 $+r-N D$ & なし & 正常の 2 倍 & $\begin{array}{l}\text { 乳頭癌, 濾胞癌, 䯣様 } \\
\text { 癌, 未分化癌の混在 }\end{array}$ \\
\hline 5 & $\begin{array}{c}\text { Burt } 5^{8)} \\
1987 \\
\end{array}$ & 39 , 女 & $*$ & $*$ & $*$ & * & 甲状腺半切除 & $*$ & 径25 & \\
\hline 6 & $\begin{array}{c}\text { Ogawa } 5^{9)} \\
1989 \\
\end{array}$ & 42 , 女 & $\begin{array}{c}407 \\
(0 \sim 90) \\
\end{array}$ & $*$ & $\begin{array}{l}29.8 \\
(0 \sim 5)\end{array}$ & 無し & 甲状腺全摘 + LN-ext & $*$ & $17 \times 12 \times 12$ & \\
\hline 7 & $\begin{array}{c}\text { Kashima } 5^{10)} \\
1993\end{array}$ & 37 ,女 & $*$ & $*$ & $*$ & 有り & 甲状腺半切除 $+\mathrm{LN}$-ext & $*$ & $30 \times 20$ & \\
\hline 8 & $\begin{array}{c}\text { Kashima } 5^{10)} \\
1993\end{array}$ & 55 ,女 & * & * & $*$ & 有り & 甲状腺半切除 $+\mathrm{LN}$-ext & $*$ & $20 \times 15$ & \\
\hline 9 & \begin{tabular}{|c|} 
Mizukami $5^{11}$ \\
1993 \\
\end{tabular} & 27 , 男 & \begin{tabular}{c|}
39000 \\
$(<170)$ \\
\end{tabular} & $\begin{array}{c}<10 \\
(<10) \\
\end{array}$ & $\begin{array}{c}248 \\
(<2.5) \\
\end{array}$ & 有り & 甲状腺全摘 + b-ND & あり & $*$ & 父と姉が䯣様癌 \\
\hline 10 & $\begin{array}{c}\text { 自験例 } \\
1996\end{array}$ & 72 ,女 & $\left|\begin{array}{c}967 \\
(<100)\end{array}\right|$ & $\begin{array}{l}81.1 \\
(<40)\end{array}$ & $\left|\begin{array}{c}121 \\
(<2.5)\end{array}\right|$ & 有り & 甲状腺全摘 $+\mathrm{I}-\mathrm{ND}$ & なし & $30 \times 40$ & 右葉に乳頭癌を合併 \\
\hline & & & & & & & \multicolumn{4}{|c|}{$\begin{array}{ll}\mathrm{CT}: \text { カルシトニン } & \text { b-ND : 両頸部郭清術 } \\
\mathrm{TG}: \text { サイログロブリン } & \mathrm{r}-\mathrm{ND}: \text { 右頸部郭清術 } \\
& \text { I-ND : 左頸部郭清術 } \\
& \text { LN-ext : リンパ節摘出 }\end{array}$} \\
\hline
\end{tabular}


索したところ, 同様に MFC の構造が確認されたため WHO の組織分類に照らし合わせ MFC と診断された。 右葉の腫瘍は H-E 染色標本により典型的な乳頭癌組織 が確認された。

MFC の組織発生に関しては未だに不明とされている がそれを考光る際には，正常甲状腺の発生から考学る必 要がある，甲状腺の発生については，従来より，滤胞細 胞は内胚葉由来の甲状舌管より生じるとされ，C細胞は， Pearse が APUD (amine precursor uptake decarboxylase) 系細胞といら概念で説明しているように，神経稜 由来の細胞よりなるとされてきた。この説に従えば MFC の発生に関しては以下の 2 点が考えられる.

第 1 K，正常の C 細胞と濾胞細胞が同時に腫瘍化して その発育段階で混在した可能性である。しかし，原発巣 にも転移巣にも同様の組織が観察されることより同時発 生的に腫瘍化したといらこの仮説は不自然と思われる。

第 2 に, 正常に発生した $\mathrm{C}$ 細胞と濾胞細胞のいずれか が単独に腫瘍化し後に混在型の腫瘍に分化していった可 能性であるが，これも転移巣に見られるといら点より疑 問が残る.

これまでに MFC が家族性に生じたとする報告11)があ り，このことから考えても偶発的な腫瘍化よりも，系統 的な腫瘍化が起こったものと考学るべきであろう。

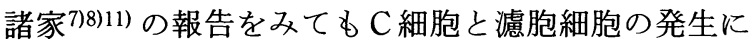
関して共通の幹細胞が存在する可能性を考えているもの が多いよらである.その幹細胞と目されているのが ultimobranchial body（鰓後体）である. 鰓後体は胎生期に第 4 鰓囊から発芽し, 咽頭囊から下降してくる甲状腺と接 合しその後甲状腺実質内に入り込み $\mathrm{C}$ 細胞に成長すると 考兄れている. Kameda ら13)によるイ又に拈いての 観察では， C 細胞複合体と呼ばれる $\mathrm{C}$ 細胞の細胞集団中 に種々の発達段階の濾胞細胞が存在し，そしてC 細胞の みならず滤胞細胞も鰓後体から生じることが確認されて いる.

ヒトにおいてもこの幹細胞である鰓後体が腫瘍化し MFC に成長したと考学れば自然かもしれない。ただし， $\mathrm{MFC}$ の報告例が未だ少ないことから考えても，すべて の濾胞細胞が鰓後体から発生するか否かは疑問である. しかし甲状腺の発生を考える上でも大変興味深いと思わ れる.

MFC は報告例そのものが少ないため，その生物学的 特性は未だ明らかではない，我々は䯣様癌に準じて経過
を観察しているが，今後の症例の蓄積と長期予後につい ての観察が必要であると思われる.

$$
\text { まとめ }
$$

1 ) mixed medullary and follicular carcinoma (MFC) に乳頭癌の合併した甲状腺腫瘍の 1 例を報告した.

2 ）臨床的には血中カルシトニン，サイログロブリン, CEA の高値を認めた。

3 ) MFC の診断のためには免疫組織染色，および転 移巣での病理組織診断が重要である.

本論文の要旨は, 第57回耳鼻咽喉科臨床学会において口演し た.

\section{参考文献}

1) Bussolati G and Monga G : Medullary carcinoma of the thyroid with atypical patterns. Cancer $44: 1769 \sim 1777$, 1979.

2) Mendelsohn G, Baylin S, Bigner S, et al : Anaplastic variants of medullary thyroid carcinoma. Am J Surg Pathol 4 : 333 341, 1980.

3 ) Martinelli G, Bazzocchi F, Govoni E, et al : Anaplastic type of medullary thyroid carcinoma. Virchows Arch Pathol 400 : 61 67, 1983.

4 ) Hales M, Rosenau W, Okerlund MD, et al : Carcinoma of the thyroid with a mixed medullary and follicular pattern. Cancer $50:$ 1352 1359, 1982.

5) Pfaltz M, Hedinger CE and Muhlethaler JP : Mixed medullary and follicular carcinoma of the thyroid. Vichows Arch [A] 400 : 53 59, 1983.

6) Ljungberg O, Ericsson U, Bonderson L, et al : A compound follicular- parafollicular cell carcinoma of the thyroid ; a new tumor entity? Cancer $52: 1053 \sim 1061,1983$.

7 ) Parker LN, Kollin J, Wu SY, et al : Carcinoma of the thyroid with a mixed medullary, papillary, follicular and undifferentiated pattern. Arch Intern Med 145 : 1507 1509, 1985.

8 ) Burt AD, MacGuire J, Lindop GB, et al : Mixed follicularparafollicular carcinoma of the thyroid. Scott Med J 32 : 50 51, 1987.

9 ) Ogawa H, Kino I and Arai T : Mixed medullary-follicular carcinoma of the thyroid. Acta Pathol Jpn $39: 67 \sim 72$, 1989.

10) Kashima $K$, Yokohama $S$, Inoue $S$, et al : Mixed medullary and follicular carcinoma of the thyroid; report of two cases with an immunohistochemical study. Acta Pathol 
Jpn $43:$ 428 433, 1993.

11) Mizukami $Y$, Michigishi $T$, Nonomura $A$, et al : Mixed medullary-follicular carcinoma of the thyroid ocurring in familial form. Histopathology 22 : 284 287, 1993.

12) Hedinger $C$, Williams ED and Sobin LH : The WHO histological classification of thyroid tumors; a commentary on the second edition. Cancer $63: 908 \sim 911,1989$.

13) Kameda $Y$, Shigemoto $H$ and Ikeda $A$ : Development and cytodifferentiation of $\mathrm{C}$ cell complexes in dog fetal thyroids. Cell Tissue Res 206 : 403 409, 1980.

$\left(\begin{array}{l}\text { 原稿受付: 平成 } 8 \text { 年 } 1 \text { 月 } 19 \text { 日 } \\ \text { 原稿採択 : 平成 } 8 \text { 年 } 2 \text { 月 } 7 \text { 日 } \\ \text { 別刷請求先 : 岩城詠子 } \\ \text { 个910 福井市下六条15-20 } \\ \text { 福井厚生病院耳鼻咽喉科 }\end{array}\right)$

